The Hippocampus in Clinical Neuroscience 
Frontiers of Neurology and Neuroscience

Vol. 34

Series Editor

J. Bogousslavsky Montreux 


\section{The Hippocampus in Clinical Neuroscience}

Volume Editors

K. Szabo Mannheim

M.G. Hennerici Mannheim

31 figures, 13 in color, and 5 tables, 2014

KARGER 
Frontiers of Neurology and Neuroscience

Vols. 1-18 were published as Monographs in Clinical Neuroscience

\author{
Prof. Dr. Kristina Szabo \\ Prof. Dr. Michael G. Hennerici \\ Department of Neurology \\ UniversitätsMedizin Mannheim \\ Theodor-Kutzer-Ufer 1-3 \\ DE-68167 Mannheim (Germany)
}

\author{
Library of Congress Cataloging-in-Publication Data \\ The hippocampus in clinical neuroscience / volume editors, K. Szabo, M.G. \\ Hennerici. \\ p. ; cm. -- (Frontiers of neurology and neuroscience, ISSN 1660-4431 \\ ; vol. 34) \\ Includes bibliographical references and indexes. \\ ISBN 978-3-318-02567-5 (hard cover : alk. paper) -- ISBN 978-3-318-02568-2 \\ (e-ISBN) \\ I. Szabo, Kristina, editor. II. Hennerici, M. (Michael), editor. III. \\ Series: Frontiers of neurology and neuroscience ; v. 34. 1660-4431 \\ [DNLM: 1. Hippocampus. W1 MO568C v. 34 2014 / WL 314] \\ QP383.25 \\ $612.8^{\prime} 25--d c 23$
}

2014010411

Bibliographic Indices. This publication is listed in bibliographic services, including Current Contents ${ }^{\circledR}$ and Index Medicus

Disclaimer. The statements, opinions and data contained in this publication are solely those of the individual authors and contributors and not of the publisher and the editor(s). The appearance of advertisements in the book is not a warranty, endorsement, or approval of the products or services advertised or of their effectiveness, quality or safety. The publisher and the editor(s) disclaim responsibility for any injury to persons or property resulting from any ideas, methods, instructions or products referred to in the content or advertisements.

Drug Dosage. The authors and the publisher have exerted every effort to ensure that drug selection and dosage set forth in this text are in accord with current recommendations and practice at the time of publication. However, in view of ongoing research, changes in government regulations, and the constant flow of information relating to drug therapy and drug reactions, the reader is urged to check the package insert for each drug for any change in indications and dosage and for added warnings and precautions. This is particularly important when the recommended agent is a new and/or infrequently employed drug.

All rights reserved. No part of this publication may be translated into other languages, reproduced or utilized in any form or by any means electronic or mechanical, including photocopying, recording, microcopying, or by any information storage and retrieval system, without permission in writing from the publisher.

(c) Copyright 2014 by S. Karger AG, P.O. Box, CH-4009 Basel (Switzerland)

www.karger.com

Printed in Germany on acid-free and non-aging paper (ISO 9706) by Kraft Druck, Ettlingen

ISSN 1660-4431

e-ISSN 1662-2804

ISBN 978-3-318-02567-5

e-ISBN 978-3-318-02568-2 


\title{
Contents
}

\author{
VII List of Contributors \\ IX Preface \\ Hennerici, M.G.; Szabo, K. (Mannheim) \\ 1 Introduction \\ Hennerici, M.G. (Mannheim)
}

Structure and Physiology of the Animal and Human Hippocampus

6 Anatomy of the Hippocampal Formation

Schultz, C.; Engelhardt, M. (Mannheim)

18 Structure and Vascularization of the Human Hippocampus

Tatu, L.; Vuillier, F. (Besançon)

26 Coordinated Network Activity in the Hippocampus

Draguhn, A.; Keller, M.; Reichinnek, S. (Heidelberg)

36 What Animals Can Teach Clinicians about the Hippocampus

Lavenex, P. (Lausanne/Fribourg); Banta Lavenex, P. (Lausanne); Favre, G. (Fribourg)

Function and Assessment of the Human Hippocampus

51 Memory Function and the Hippocampus

Opitz, B. (Guildford)

60 Neuropsychological Measures of Hippocampal Function

Wicking, M.; Nees, F.; Steiger, F. (Mannheim)

71 Conventional and Diffusion-Weighted MRI of the Hippocampus

Szabo, K.; Förster, A.; Gass, A. (Mannheim)

85 Functional MRI Studies of the Hippocampus

Nees, F.; Pohlack, S.T. (Mannheim)

The Hippocampus in Neurological Disorders

95 The Hippocampus in Neurodegenerative Disease

Moodley, K.K.; Chan, D. (Brighton)

109 Stress, Memory, and the Hippocampus

Wingenfeld, K. (Berlin); Wolf, O.T. (Bochum) 
121 Epilepsy and the Hippocampus

Chatzikonstantinou, A. (Mannheim)

143 Transient Global Amnesia

Szabo, K. (Mannheim)

150 Hippocampal Stroke

Szabo, K. (Mannheim)

157 Author Index

158 Subject Index 


\section{List of Contributors}

\section{Dr. Pamela Banta Lavenex}

Laboratory for Experimental Research on Behavior, Institute of Psychology

University of Lausanne, Géopolis 4524

CH-1015 Lausanne (Switzerland)

E-Mail pamela.bantalavenex@unil.ch

\section{Dr. Dennis Chan}

Herchel Smith Building for Brain and

Mind Sciences

University of Cambridge

Forvie Site, Robinson Way

Cambridge CB2 0SZ (UK)

E-Mail dc598@medschl.cam.ac.uk

\section{Dr. Anastasios Chatzikonstantinou}

Department of Neurology

UniversitätsMedizin Mannheim

Theodor-Kutzer-Ufer 1-3

DE-68167 Mannheim (Germany)

E-Mail chatziko@neuro.ma.uni-heidelberg.de

\section{Prof. Dr. Andreas Draguhn}

Institut für Physiologie und Pathophysiologie, Universität Heidelberg

Im Neuenheimer Feld 326

DE-69120 Heidelberg (Germany)

E-Mail andreas.draguhn@

physiologie.uni-heidelberg.de

\section{Dr. rer. nat. Maren Engelhardt}

Institute of Neuroanatomy

Center for Biomedicine and Medical Technology

Mannheim (CBTM)

Medical Faculty Mannheim/Heidelberg

University

Ludolf-Krehl Str. 13-17

DE-68167 Mannheim (Germany)

E-Mail maren.engelhardt@

medma.uni-heidelberg.de

\section{Dr. Grégoire Favre}

Unité de Psychiatrie et de Psychothérapie

Département de Médecine

Université de Fribourg

Chemin du Musée 5

$\mathrm{CH}-1700$ Fribourg (Switzerland)

E-Mail gregoire.favre@unifr.ch

\section{Dr. Alex Förster}

Department of Neurology

UniversitätsMedizin Mannheim

Theodor-Kutzer-Ufer 1-3

DE-68167 Mannheim (Germany)

E-Mail alex.foerster@umm.de

\section{Dr. Achim Gass}

Department of Neurology

UniversitätsMedizin Mannheim

Theodor-Kutzer-Ufer 1-3

DE-68167 Mannheim (Germany)

E-Mail achim.gass@medma.uni-heidelberg.de

\section{Prof. Dr. Michael G. Hennerici}

Department of Neurology

UniversitätsMedizin Mannheim

Theodor-Kutzer-Ufer 1-3

DE-68167 Mannheim (Germany)

E-Mail hennerici@neuro.ma.uni-heidelberg.de

\section{Martin Keller}

Institut für Physiologie und Pathophysiologie

Universität Heidelberg

Im Neuenheimer Feld 326

DE-69120 Heidelberg (Germany)

E-Mail martin.k.keller@gmail.com 
Prof. Dr. Pierre Lavenex

Laboratory for Experimental Research on

Behavior, Institute of Psychology

University of Lausanne, Géopolis 4343

$\mathrm{CH}-1015$ Lausanne (Switzerland)

E-Mail pierre.lavenex@unil.ch

Dr. K.K. Moodley

Clinical Research Fellow

Clinical Imaging Sciences Centre

Brighton and Sussex Medical School

Falmer, Brighton BN1 9RR (UK)

E-Mail K.moodley2@bsms.ac.uk

\section{Frauke Nees, PhD}

Department of Cognitive and Clinical

Neuroscience, Central Institute of Mental Health

Square $J 5$

DE-68159 Mannheim (Germany)

E-Mail frauke.nees@zi-mannheim.de

\section{Prof. Dr. Bertram Opitz}

School of Psychology, University of Surrey

Guildford GU2 7XH (UK)

E-Mail b.opitz@surrey.ac.uk

\section{Dr. Sebastian Pohlack}

Department of Cognitive and

Clinical Neuroscience

Central Institute of Mental Health, Square J 5

DE-68159 Mannheim (Germany)

E-Mail sebastian.pohlack@zi-mannheim.de

\section{Dr. Susanne Reichinnek}

Institut für Physiologie und Pathophysiologie

Universität Heidelberg

Im Neuenheimer Feld 326

DE-69120 Heidelberg (Germany)

E-Mail susanne.reichinnek@gmx.de

\section{Prof. Dr. med. Christian Schultz}

Institute of Neuroanatomy

Center for Biomedicine and Medical Technology

Mannheim (CBTM)

Medical Faculty Mannheim/Heidelberg

University

Ludolf-Krehl Str. 13-17

DE-68167 Mannheim (Germany)

E-Mail christian.schultz@ medma.uni-heidelberg.de
Frauke Steiger

Department of Cognitive and Clinical

Neuroscience, Central Institute of Mental Health

Square $J 5$

DE-68159 Mannheim (Germany)

E-Mail frauke.steiger@zi-mannheim.de

Prof. Dr. Kristina Szabo

Department of Neurology

UniversitätsMedizin Mannheim

Theodor-Kutzer-Ufer 1-3

DE-68167 Mannheim (Germany)

E-Mail szabo@neuro.ma.uni-heidelberg.de

\section{Prof. Laurent Tatu}

Department of Neuromuscular diseases

CHU Jean-Minjoz

Boulevard Fleming

FR-25030 Besançon Cedex (France)

E-Mail laurent.tatu@univ-fcomte.fr

\section{Dr. Fabrice Vuillier}

Departments of Anatomy and Neurology

CHU Besançon

2 Boulevard Fleming

FR-25000 Besançon (France)

E-Mail fabrice.vuillier@univ-fcomte.fr

\section{Manon Wicking}

Department of Cognitive and Clinical

Neuroscience, Central Institute of Mental Health

Square $\mathrm{J} 5$

DE-68159 Mannheim (Germany)

E-Mail manon.wicking@zi-mannheim.de

\section{Prof. Dr. Katja Wingenfeld}

Department of Psychiatry

Charité University Berlin

Campus Benjamin Franklin

Eschenallee 3

DE-14050 Berlin (Germany)

E-Mail katja.wingenfeld@charite.de

\section{Prof. Dr. Oliver T. Wolf}

Department of Cognitive Psychology

Ruhr University Bochum

GAFO 02/386

Universitätsstrasse 150

DE-44780 Bochum (Germany)

E-Mail oliver.t.wolf@rub.de 


\section{Preface}

This publication is the result of many years of clinical and academic interest in the hippocampus, perhaps the most intriguing structure of the human brain. Damage to this structure, one of the oldest parts of the brain integrated in highly complex networks, causes symptoms ranging from transient dysfunction accompanied by tiny lesions to severely debilitating cognitive disorders with marked tissue loss. Besides the motivation to provide information on clinical function and dysfunction of the hippocampus from a neurologist's point of view, several other chapters arose from discussions with expert colleagues from other neuroscience disciplines participating in our collaborative research effort dedicated to 'learning, memory, and brain plasticity'.

Although overlaps between the different fields of hippocampus research, by their very nature, cannot be avoided completely, the editors allocated the individual contributions to three general sections. Section 1 of the book summarizes the current knowledge regarding structure and physiology of the hippocampus, and establishes the ties to basic neuroscience. Section 2 deals with the function of the hippocampus in humans and its assessment. Finally, Section 3 reviews common pathological conditions affecting the hippocampus with a chapter devoted to the effects of stress on hippocampus-mediated memory function and its relevance for selected disorders.

We wish to thank the editorial staff at Karger Publishers for their continuous guidance and advice, and all of the contributing authors for the time and effort they have invested in this project. We hope the reader will enjoy the book as much as we did preparing it, and will find it instructional and useful.

Michael G. Hennerici, Mannheim Kristina Szabo, Mannheim 
